\title{
Moderasi Dakwah Syekh Yusuf Al-Makassari
}

\author{
Ismail Suardi Wekke \\ Southeast Asia Academic Mobility (SEAAM) \\ Email: iswekke@gmail.com \\ Achmad Shabir \\ Universitas Negeri Makassar \\ Email: achmadshabir@unm.ac.id
}

Adil Zulkifli

Universitas Negeri Makassar

Email: azulkifli@gmail.com

\begin{abstract}
ABSTRAK
Pesan dakwah Syekh Yusuf Al-Makassari mencerminkan nilai-nilai Islam yang damai dan toleran terhadap kelompok agama lain sehingga jauh dari kesan anarkis dan ekstrim (Ansori, 2018). Seminar ini bertujuan untuk mengekplorasi kekayaan metode dan pesan dakwah Syekh Yusuf Al-Makassari yang moderat, damai dan toleran terhadap pemeluk agama lainnya serta memberi kesempatan yang sama pada setiap ras dan suku bangsa.
\end{abstract}

Kata Kunci: moderat; dakwah; Syekh Yusuf.

\section{Pendahuluan}

Syekh Yusuf Tajul Khalwaty, atau lebih dikenal dengan nama Tuanta Salamaka (Tuan Kita yang Selamat) lahir di Moncongloe, Gowa pada 3 Juli 1626 atau bertepatan dengan 8 Syawal 1036 Hijriah dengan nama Muhammad Yusuf. Tambahan gelar Syekh disematkan padanya usai belajar ke timur tengah dan menunaikan ibadah Haji di Tanah Suci, Mekah.

Ayahnya, Abdullah adalah sufi keturunan Arab dari Aceh. Sedangkan Ibunya, Siti Aminah Itulbiani Daeng Kunjung Karaeng Baji adalah putri bangsawan Gallarang Moncong Loe di era Sultan Alauddin, Raja Gowa XIV.

Meski terlahir di Gowa, namun Syekh Yusuf menghabiskan sebagian besar hidupnya berdakwah di negeri orang. Jumlah pengikutnya selalu bertambah dan menjadi ulama panutan di setiap tempat yang disinggahi. Tak heran, meski beliau wafat di Afrika Selatan pada 23 Mei 1699 namun memiliki lima makam yang tersebar di tiga negara, yakni; Tanjung Harapan (Afrika Selatan), Sailon (Srilanka), Banten (Jawa Barat), Sumenep (Jawa Timur) dan di Gowa, (Sulawesi Selatan).

Kelima makam ini menunjukkan ketokohan Syekh Yusuf yang mengakar di wilayah tersebut. Meski demikian, makam di Gowa diyakini sebagai kuburan asli (Kila, 2018). Ini berdasarkan pengabulan permintaan Raja Gowa XIX Sultan Abdul Jalil Tumenanga ri Lakiung oleh Pemerintah Belanda pada tahun 1704. Keranda beserta tulang belulang Syekh Yusuf tiba di Gowa pada 5 April 1705 (Farid, 2017) (Quinn, 2009). Sementara di Afrika Selatan, negara tempat meninggalnya, yang dimakamkan adalah sorban dan jubah beliau. Begitu juga makam yang ada di Banten, Sumenep dan Srilanka (Kila, 2018).

Bukti lain ketokohan Syekh Yusuf adalah gelar pahlawan nasional yang diberikan oleh dua negara lintas benua, yakni Republik Indonesia dan Republik Afrika Selatan. Gelar pahlawan nasional diberikan Presiden RI Soeharto pada 7 Agustus 1995. Sementara Republik Afrika Selatan memberikan penghargaan Gold-Order of the Companions of Oliver Reginald 
Tambo pada 27 September 2005 (South African Government, 2005), yakni penghargaan tertinggi yang ditujukan untuk tokoh asing yang berjasa bagi Negara Afrika Selatan.

Penghargaan tersebut diserahkan oleh Presiden Afrika Selatan Thabo Mbeki kepada perwakilan keluarga Syekh Yusuf, H. Andi Makmun Bau Tayang di Union Building Pretoria, Afrika Selatan. Upacara penyerahan penghargaan tersebut disaksikan oleh Wakil Presiden Jusuf Kalla dan istri, Menteri Luar Negeri Hassan Wirajudha, Menteri Agama Maftuh Basyuni, Wakil Ketua MPR A.M Fatwa dan Gubernur Sulawesi Selatan Syahrul Yasin Limpo serta Duta Besar RI untuk Afrika Selatan Abdul Nasir. (liputan6, 2005)

Selama 300 tahun lamanya, nama Syekh Yusuf tidak begitu dikenal dunia bahkan terkesan terlupakan, termasuk oleh Pemerintah Republik Indonesia. Namanya mulai mendapatkan perhatian dunia saat Presiden Afrika Selatan periode 1994-1999, Nelson Mandela menyebut Syech Yusuf sebagai tokoh yang menginspirasi perjuangannya menentang praktik politik apartheid (Erman, 2012).

Pernyataan itu disampaikan Nelson Mandela dalam peringatan 300 tahun kedatangan Syekh Yusuf di Cape Town, Afrika Selatan pada Tahun 1994. Dia mengatakan, "Dia (Syekh Yusuf) adalah putra Afrika Selatan dan insprirasi perjuangan anti-apartheid. Dia adalah inisiator terbentuknya komunitas Afrika Selatan. Saya mendapatkan inspirasi dari beliau, bahwa kulit hitam dan kulit putih adalah setara, bahwa bangsawan dan budak tidaklah berbeda. Apa yang membedakan manusia di depan Tuhan adalah kedalaman imannya."

"He is son of South Africa and the inspiration for the anti-apartheid struggle. He was the initiator of the establishment of the South African community. I got inspiration from him that the black and white are the same, that the nobles dan slaves are no different. What makes different men before the God is the value of their faith." (Erman, 2012)

Pernyataan ini mengkonfirmasi bahwa Syekh Yusuf mendakwahkan ajaran Islam yang bersifat universal, termasuk di dalamnya Hak Asasi Manusia, selama masa pembuangan di Ceylon, Srilanka dan Cape Town, Afrika Selatan. Sasaran dakwah beliau adalah komunitaskomunitas budak yang sama-sama tertindas oleh VOC Belanda di dua negara tersebut.

Seminar tentang Tuanta Salamaka Syekh Yusuf Al-Makassari sebelumnya sudah pernah digelar pada 10 November 2011 di Makassar oleh Konsulat Jenderal Republik Indonesia untuk Cape Town, Afrika Selatan bekerja sama dengan Universitas Hasanuddin (Antaranews, 2011). Seminar tersebut fokus pada penelusuran sejarah dan peran Syekh Yusuf dalam melawan penjajahan di Afrika Selatan. Namun hingga saat ini, belum ada seminar digelar berkaitan dengan corak dakwah Syekh Yusuf Al-Makassari yang moderat, damai dan toleran.

Menurut Ansori (2018), "Pesan dakwah tentang kajian etika religius Al-Makassari melambangkan dan mencerminkan nilai-nilai Islam yang damai, toleran dan menolak intoleransi, ramah, dan tidak anarkisme dan antiterorisme terhadap golongan-golongan lain."

Sikap toleran ini sesuai dengan esensi ajaran Islam. Islam telah mengaplikasikan toleransi terhadap keberagaman, 10 abad sebelum lahirnya The Toleration Act di Eropa pada tahun 1689. Piagam Madinah merupakan salah satu bukti otentik. Konstitusi tertulis ini menyatakan bahwa semua golongan agama dan suku yang berada di Madinah mempunyai hak, perlakuan dan kewajiban yang sama, tanpa harus memaksakan kehendak kepada golongan lain baik dari segi keagamaan maupun sosial.

Konstitusi ini terdiri atas 47 pasal dan dicap tangan oleh Rasulullah Muhammad SAW pada 622 M. 23 pasal mengatur hubungan antara umat Islam, yaitu antara Kaum Anshar (pribumi) dan Muhajirin (pendatang). Dan 24 pasal lainnya mengatur hubungan muslim dengan penganut agama lainnya (Irawan, 2015).

Metode dakwah Syekh Yusuf sesuai dengan teladan yang dicontohkan Rasulullah SAW. Dakwah yang sangat moderat, adaptif dan menjunjung tinggi nilai-nilai toleransi. Coraknya 
mencerahkan, merangkul dan mengayomi, tidak memaksa dan tidak menggunakan cara-cara anarkis terhadap golongan agama lainnya (Ansori, 2018). Corak ini sangat berbeda dengan corak dakwah mayoritas ulama populer hari ini di Indonesia yang mengedepankan gaya orasi keras dan diksi yang menyulut perbedaan, serta menggunakan ayat-ayat 'pedang'.

Tak heran jika fenomena ini mendapat perhatian khusus dari Pemerintahan JokowiMa'ruf Amin yang khawatir dengan potensi disintegrasi bangsa yang diakibatkan oleh isu SARA. Disisi lain, program deradikalisasi yang dijalankan Pemerintah RI seyogyanya juga bercermin pada jalan dakwah Syekh Yusuf yang tidak menggunakan perangkat militer selama menjadi Mufti Besar/penasehat Kesultanan Banten.

Moderasi dakwah ala Syekh Yusuf ini sangat relevan diterapkan di Indonesia yang multikultur, multietnis dan mengakui enam agama resmi. Apalagi di tengah menguatnya isu SARA dan politik identitas yang menggerogoti tradisi bhinneka tunggal ika dalam kehidupan masyarakat Indonesia. Prinsip beragam tapi satu sebagai ruh Pancasila, sangat perlu dibumikan kembali demi menjaga persatuan dan kesatuan bangsa Indonesia.

Penguatan nilai Pancasila, terutama yang berkaitan dengan de-radikalisasi paham-paham ekstrimis berbasis agama akan lebih tepat diselenggarakan melalui kampanye moderasi dakwah Syekh Yusuf Al-Makassari. Mengingat mayoritas penduduk Indonesia, sekitar 87,2\% beragama muslim (Pew Research Center, 2009) dan rentan terhadap paparan paham-paham ekstrimis.

Karenanya dirasa perlu dan urgen untuk menggelar seminar International berkaitan dengan moderasi dakwah yang selama ini dicontohkan Syekh Yusuf Al-Makassari. Dengan harapan masyarakat Sulawesi Selatan dan rakyat Republik Indonesia tidak larut dalam buaian paham-paham ekstrimis yang menyesatkan.

\section{Gambaran Singkat}

Seminar ini akan menghadirkan akademisi universitas dari berbagai negara yang telah melakukan riset mengenai Syekh Yusuf Al-Makassari seperti Malaysia, Inggris, Belanda, Amerika Serikat, Australia dan lain sebagainya. Paling tidak ada tiga scholar dari tiga negara yang menjadi pembicara utama, yakni Indonesia, Srilanka dan Afrika Selatan. Dan tidak menutup kemungkinan akan bertambah.

Output yang diharapkan adalah prosiding dan atau jurnal ilmiah yang terindeks di pangkalan data bereputasi serta buku yang juga dapat ditemukan di platform terkemuka dunia tentang moderasi dakwah Syekh Yusuf Al-Makassari.

Dampak lain dari seminar ini adalah kunjungan wisata mancanegara ke Kabupaten Gowa dalam rangka menghadiri seminar dan mengunjungi makam Syekh Yusuf di Kobbang, Lakiung.

Selain itu, dimungkinkan pula bagi Bupati Gowa untuk menyampaikan hasil-hasil seminar tentang Moderasi Dakwah Syekh Yusuf Al-Makassari dalam kuliah umum di Oxford University dan atau Harvard University. Kuliah umum tersebut merupakan langkah tindak lanjut yang diharapkan dari seminar internasional ini.

\section{Jadwal Kegiatan}

Kegiatan ini direncanakan pada 3 Juli 2020. Tanggal ini dipilih untuk memperingati 394 tahun kelahiran Syekh Yusuf Al-Makassari di Kabupaten Gowa.

Rangkaian seminar ini akan dilaksanakan selama 3 hari seluruhnya bertempat di wilayah administrasi Kabupaten Gowa. Dengan harapan kegiatan tersebut memberikan input pendapatan daerah bagi Kabupaten Gowa dan masyarakat Gowa dari sektor pariwisata.

Kegiatan utama yakni pembukaan dan seminar akan dilaksanakan di Malino, selama 2 hari. Kemudian dilanjutkan dengan kunjungan wisata pada esok harinya ke makam Syekh 
Yusuf di Kobbang dan Benteng Somba Opu. Gala Dinner di atas perahu phinisi di Pantai Barombong akan menjadi penutup seluruh rangkaian kegiatan.

\section{Penutup}

Artikel ini sebagai gambaran awal terkait moderasi dakwah Syekh Yusuf Al-Makassari. Sehingga detail perencanaan teknis dan operasional perlu dijabarkan dalam bentuk tindak lanjut. Semoga rencana kegiatan ini, dapat bermanfaat bagi pengembangan keilmuan dan pembangunan masyarakat Kabupaten Gowa pada khususnya, dan Sulawesi Selatan. Untuk tindaklanjut, sebagai rintisan sudah dilaksanakan identifikasi topik filsafat dan etika (Sainuddin \& Wekke, 2020), ulama pejuang (Wekke, 2020), pendidikan dan perjuangan dakwah (Wekke, Rajjako, \& Harisman, 2020).

\section{Daftar Pustaka}

Ansori, A. (2018). Urgensi Etika dalam Pendidikan Akhlak Islam menurut Perspektif Yusuf al-Makassari. EL-BANAT: Jurnal Pemikiran Dan Pendidikan Islam, 8(1), 155-170.

Antaranews. (2011). Syekh Yusuf di Afsel diseminarkan di Makassar. (R. Burhani, Produser, \& Antaranews) Dipetik Januari 2020, dari www.antaranews.com: https://www.antaranews.com/berita/283772/syekh-yusuf-di-afsel-diseminarkan-dimakassar

Bakhri, S. (n.d.). Kebhinnekaan, Sikap Jalan Tengah dan Penegakan Hukum.

Erman, E. (2012). Remembering and Forgetting: The History of Sheikh Yusuf Struggle for Human Rights. Heritage of Nusantara: International Journal of Religious Literature and Heritage, 1(1), 101-122.

Farid, A. Z. (2017). Capita Selecta: Sejarah Sulawesi Selatan (Vol. 2). (S. Sabang, Ed.) Makassar, Sulawesi Selatan, Indonesia: CV. Social Politic Genius (SIGn).

Irawan, C. P. (2015). Konstitusi Negara Khilafah. Jurnal Sharia Law, 1, 1-5.

Kila, S. (2018). Syekh Yusuf: Pahlawan Nasional Dua Bangsa Lintas Benua. Walasuji: Jurnal Sejarah dan Budaya, 9(2), 237-248.

Liputan6. (2005). Wakil Presiden Bertolak ke Afrika Selatan. Dipetik Januari 2020, dari www.liputan6.com: https://www.liputan6.com/news/read/109761/wakil-presidenbertolak-ke-afrika-selatan

Pew Research Center. (2009). Mapping the Global Muslim Population. Dipetik Januari 2020, dari www.pewforum.org: https://www.pewforum.org/2009/10/07/mapping-the-globalmuslim-population/

Quinn, G. (2009). Where History Meets Pilgrimage: The Graves of Sheikh Yusuf Al-Maqasari and Prince Dipanagara. Journal of Indonesian Islam, 3(2), 249-266.

Sainuddin, I. H., \& Wekke, I. S. (2020). Syekh Yusuf Al-Makassari: Pandangan Etika dan Filsafat. https://doi.org/10.31219/osf.io/g8cuk.

South African Government. (2005). National Orders awards 27 September 2005. Dipetik Januari 2020, dari www.gov.za: https://www.gov.za/about-government/national-ordersawards-27-september-2005

Wekke, I. S. (2020). Syekh Yusuf dalam Semangat Perjuangan Kemerdekaan. https://doi.org/10.31219/osf.io/7wh9m.

Wekke, I. S., Rajjako, A., \& Harisman, T. (2020). Syekh Yusuf, Mengenang Perjuangan dan Kejuangan Dengan Spirit Keagamaan. https://doi.org/10.31219/osf.io/vfgkq. 